\title{
ВПЛИВ ПИТНОЇ ВОДИ З РІЗНИМ ВМІСТОМ СТЕАРАТІВ КАЛІЮ І НАТРІЮ НА ВІЛЬНОРАДИКАЛЬНІ ПРОЦЕСИ В ОРГАНІЗМІ ЩУРІВ
}

Вступ. Однією з причин поганої якості питної води є низька якість природної води, яка постійно забруднюється стічними водами промислових та комунальних підприємств, поверхневими стоками з полів і територій населених пунктів, з якими в неї потрапляє велика кількість токсичних речовин. Серед них не останнє місце займають поверхнево-активні речовини, такі, як стеарати калію та натрію.

Мета дослідження - встановити особливості пероксидного окиснення ліпідів і стан антиоксидантного захисту при впливі на організм піддослідних тварин стеаратів калію та натрію, які надходять 3 питною водою.

Методи дослідження. У роботі використовували білих щурів, поділених на 7 груп, які впродовж 25 днів вживали воду зі стеаратами в кількості, що дорівнювала максимально недіючій дозі речовини (МНД), 1/2 МНД та 1/4 МНД. Визначали вміст ТБК-активних продуктів пероксидного окиснення ліпідів, дієнові кон'югати й активність супероксиддисмутази і каталази в гомогенаті печінки.

Результати й обговорення. У гомогенаті печінки тварин усіх груп відмічали достовірне зростання рівня дієнових кон'югатів і ТБК-активних продуктів пропорційно до концентрації речовини. Також було встановлено, що в щурів, які вживали воду з різною концентрацією стеарату калію, спостерігали пригнічення ензимів антиоксидантного захисту. Вживання води з різною концентрацією стеарату натрію викликало активацію цих ензимів.

Висновки. Тривале вживання піддослідними тваринами водного розчину з концентрацією стеаратів калію і натрію в МНД та 1/2 МНД негативно впливає на стан клітинних мембран гепатоцитів внаслідок активації процесів пероксидного окиснення ліпідів, а саме ТБК-активних продуктів і дієнових кон'югатів, кількість яких залежить від концентрації стеаратів у питній воді. Вживання піддослідними тваринами питної води з вмістом стеаратів калію та натрію в різних дозах зумовлює зміни рівня ензимів антиоксидантного захисту: вода зі стеаратом калію пригнічує активність цих показників, а зі стеаратом натрію викликає активацію.

КЛЮЧОВІ СЛОВА: стеарат калію; стеарат натрію; пероксидне окиснення ліпідів; антиоксидантний захист; ТБК-активні продукти; дієнові кон'югати; каталаза; супероксиддисмутаза.

ВСТУП. Проблема забезпечення населення доброякісною питною водою в Україні, як і в інших країнах, залишається невирішеною, а в ряді регіонів - набуває кризового характеру. Однією з причин поганої якості питної води є низька якість природної води, яка постійно забруднюється стічними водами промислових та комунальних підприємств, поверхневими стоками 3 полів і територій населених пунктів, з якими в неї потрапляє велика кількість токсичних речовин $[1,2]$. Серед них не останнє місце займають поверхнево-активні речовини, такі, як стеарати калію та натрію. Їх широко використовують у виробництві мийних засобів, шампунів, фрарб для волосся, кремів для рук, піни для гоління, як добавку до зубних паст та косметичних кремів, с О. В. Лотоцька, 2018. вони є одними з основних компонентів твердого і рідкого мил. Також стеарати калію та натрію застосовують у виробництві поліолефінів, каучуків і гуми, в сухих будівельних сумішах, при переробці термопластиків, як загусник мастил, стабілізатор і мастило при фрормуванні поліамідів, антиспінювач у харчовій промисловості, лубрикант у паперовій промисловості [3, 4]. Незважаючи на широке використання стеаратів калію та натрію, даних щодо вивчення їх санітарно-гігієнічних і токсикологічних властивостей мало.

Поверхнево-активні речовини - малотоксичні для тварин і людини речовини. У високих дозах вони здатні проявляти інактивуючий або стимулювальний ефект на фрерментні системи, порушувати обмінні процеси в печінці, нирках, 
шлунково-кишковому тракті, кровотворній та нервовій системах $[5,6]$. В експериментах на тваринах учені встановили, що вони істотно змінюють інтенсивність окисно-відновних реакцій, впливають на активність ряду найважливіших орерментів, порушують білковий, вуглеводний і жировий обмін [7-9].

Доведено, що тканини печінки на тривалий час затримують аніонні поверхнево-активні речовини, які входять до складу синтетичних мийних засобів, що викликає різке збільшення проникності клітинних мембран печінки $[8,10]$. Даної інорормації недостатньо для прогнозування наслідків впливу цих чинників на здоров'я населення. Тому доцільним було проведення підгострого експерименту з метою встановлення потенційної токсичної дії поверхнево-активних речовин на організм піддослідних щурів при надходженні з питною водою за умов їх нормативного та понаднормативного вмісту.

В останні роки чимало досліджень присвячено процесам пероксидного окиснення ліпідів (ПОЛ). Це великою мірою зумовлено тим, що дефект у зазначеній ланці метаболізму здатний суттєво знизити резистентність організму до впливу на нього несприятливих чинників зовнішнього та внутрішнього середовища.

Мета дослідження - встановити особливості пероксидного окиснення ліпідів і стан антиоксидантного захисту (АО3) при впливі на організм піддослідних тварин стеаратів калію та натрію, які надходять 3 питною водою.

МЕТОДИ ДОСЛІДЖЕННЯ. Досліди проведено на 42 білих безпородних щурах-самцях масою 160-180 г. Групи відбирали методом рандомізації. Експерименти виконували відповідно до Європейської конвенції про захист хребетних тварин, що використовуються для дослідних та інших наукових цілей (Страсбург, 1986), норм біомедичної етики і Загальних етичних принципів експериментів на тваринах, ухвалених на Першому національному конгресі з біоетики (Київ, 2001).

Тварини перебували на загальноприйнятому раціоні віварію в однакових умовах і відрізнялися лише за якістю питної води, яку вживали з автопоїлок. Для вивчення впливу стеаратів калію та натрію на організм піддослідних тварин усіх щурів поділили на 7 груп по 6 тварин у кожній. Усі вони впродовж 25 днів вживали воду зі стеаратами в різній кількості. Тварини 1-ї (контрольної) групи вживали воду з міського водогону, 2-ї - питну воду з вмістом стеарату калію в кількості 125,0 мг/дм³ (що дорівнювало максимально недіючій дозі (МНД) речовини), 3-ї 62,5 мг/дм³ (або 1/2 МНД), 4-ї - 31,2 мг/дм³ (або
1/4 МНД), 5-ї - питну воду з вмістом стеарату натрію в кількості 80,0 мг/дм³ (що дорівнювало МНД речовини), 6-ї - 40,0 мг/дм³ (або 1/2 МНД), 7-ї - 20,0 мг/дм³ (або 1/4 МНД).

Тварин виводили 3 експерименту шляхом кровопускання під тіопентал-натрієвим наркозом через 30 днів від початку досліду. Вміст ТБК-активних продуктів (ТБК-АП) визначали в гомогенаті печінки за реакцією з тіобарбітуровою кислотою [11], кількість дієнових кон'югатів (ДК) - за інтенсивністю поглинання світла гептановою фрракцією [12]. Стан антиоксидантної системи оцінювали за активністю основних ензимів антиоксидантного захисту - супероксиддисмутази (СОД) [13] і каталази (КТ) [14]. Експериментальні дані опрацьовували методом варіаційної статистики з визначенням критерію Стьюдента і ступеня достовірності, використовуючи комп'ютерну програму Excel [15].

РЕЗУЛЬТАТИ Й ОБГОВОРЕННЯ. ПРИ ВЖИванні води з різною концентрацією стеарату калію на 25 добу експерименту в гомогенаті печінки тварин 2-ї групи відмічали зростання ДК у 2,2 раза $(\mathrm{p}<0,05)$, в 3-й групі - в 1,5 раза $(p<0,05)$, а в 4-й цей показник був практично на рівні контрольних величин (рис. 1).

Наступним показником, який ми визначали, були ТБК-активні продукти ПОЛ. Їх збільшення свідчило про раннє виявлення метаболічних порушень в організмі, навіть на доклінічній стадії захворювання. Як видно з рисунка 1, концентрація цього показника в трьох перших дослідних групах була прямо пропорційною до кількості стеарату калію в питній воді. Так, у щурів 2-ї групи рівень ТБК-АП зріс у 2,4 раза $(p<0,05)$, в 3-й групі - в 1,6 раза $(p<0,05)$ і в 4-й - майже не відрізнявся від контрольної групи.

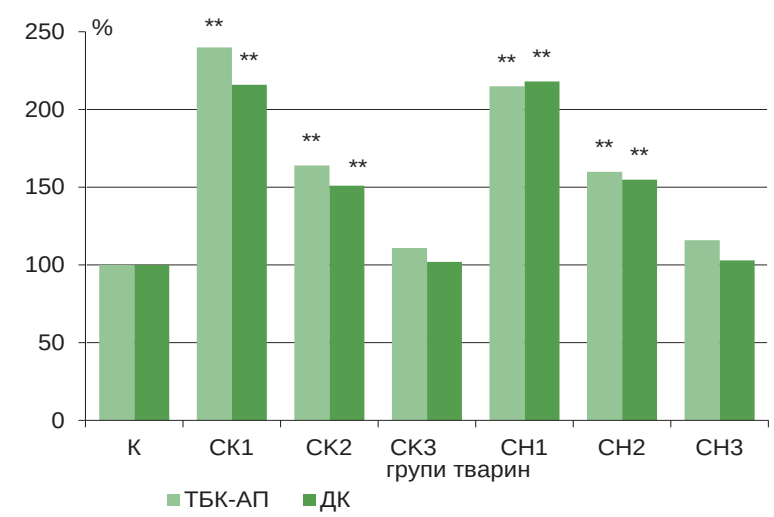

Рис. 1. Зміни показників пероксидного окиснення ліпідів у гомогенаті печінки піддослідних тварин при вживанні питної води з різним вмістом стеаратів калію та натрію.

Примітка. Тут і на рисунку 2 :

1. * - достовірність відмінностей показників дослідних і контрольної груп (* $-p<0,1 ;{ }^{* *}-p<0,05$; ** $\left.-p<0,01\right)$.

2. К - контроль; СК - стеарат калію; СН - стеарат натрію. 
У тварин, які вживали воду зі стеаратом натрію, спостерігали менш виражені зміни даних показників: у гомогенаті печінки тварин 5-ї групи відмічали зростання ДК та ТБК-АП ПОЛ прак-

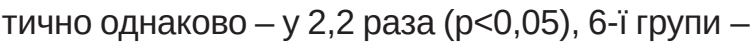
в 1,6 раза $(p<0,05)$. У щурів 7-ї групи різниці 3 контролем практично не відзначали (рис. 1).

Відомо, що продукти ПОЛ є мембранотоксичними, вони здатні десрормувати мембрани клітин, порушувати їх осмотичну резистентність і електричний потенціал, окиснювати тіолові сполуки та SH-групи білків мембран, розривати нуклеїнові кислоти, денатурувати білки і руйнувати амінокислоти. Проте пошкоджувальна дія вільних радикалів стримується системою антиоксидантів, її ензимною та неензимною ланками, а збереження рівноваги між процесами ПОЛ та системи АОЗ $є$ запорукою збереження цілісності органа. Причиною посилення вільнорадикального окиснення може бути зниження активності системи AO3, що здатна знешкоджувати активні фрорми кисню, які і $є$ безпосередніми ініціаторами ПОЛ. Проведені дослідження активності антиоксидантних ензимів підтвердили це.

Вплив стеарату калію на АОЗ організму піддослідних тварин оцінювали шляхом аналізу активності КТ та вмісту СОД у гомогенаті печінки. На 30-ту добу у тварин, які вживали воду з різною концентрацією стеарату калію, спостерігали пригнічення активності цих показників (рис. 2).

У 2-й дослідній групі відзначали зменшення СОДу 2,4 раза $(p<0,05)$, в 3-й - 1,8 раза $(p<0,05)$ порівняно $з$ контрольною групою. Щодо КТ, то спостерігали такі зміни: у 2-й групі активність ензиму знизилась в 1,9 раза $(p<0,05)$, в 3-й - в 1,2 раза $(p<0,05)$, в 4-й обидва показника мало відрізнялися від контролю.

Вживання води з різною концентрацією стеарату натрію викликало активацію ензимів АОЗ. У 5-й групі рівень КТ у гомогенаті печінки збільшився в 1,4 раза $(p<0,01)$, а СОД - у 2,0 рази $(p<0,05)$. У 6 -й групі зміни були менш виражени-

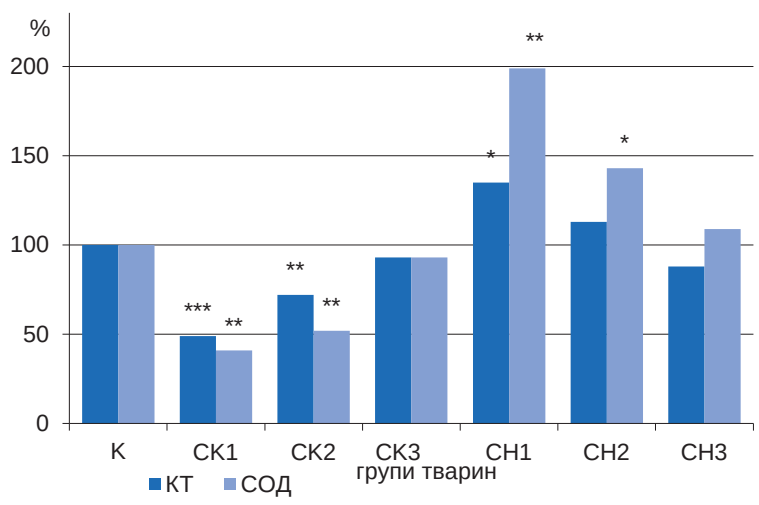

Рис. 2. Зміни показників антиоксидантного захисту в гомогенаті печінки піддослідних тварин при вживанні питної води з різним вмістом стеаратів калію та натрію.

ми, хоча збереглася тенденція до зростання КТ, а кількість СОД в 1,4 раза була вищою порівняно 3 контрольною групою $(p<0,01)$. У 7 -й групі показники мало відрізнялися від контрольних величин.

Отже, активація ПОЛ може бути неспецифрічною патогенетичною ланкою формування патологічних змін в організмі за змодельованих умов, а зрив антиоксидантного захисту внаслідок такого впливу сприяє посиленню руйнації мембран та порушенню структурних і фрункціональних їх властивостей.

ВИСНОВКИ. 1. Тривале вживання піддослідними тваринами водного розчину з концентрацією стеаратів калію і натрію в МНД та 1/2 МНД негативно впливає на стан клітинних мембран гепатоцитів внаслідок активації процесів ПОЛ, а саме ТБК-активних продуктів та дієнових кон'югатів, кількість яких залежить від концентрації стеаратів у питній воді.

2. Вживання піддослідними тваринами питної води з вмістом стеаратів калію та натрію в різних дозах зумовлює зміни рівня ензимів антиоксидантного захисту: вода зі стеаратом калію пригнічує активність цих показників, а зі стеаратом натрію - викликає активацію.

\section{СПИСОК ЛІТЕРАТУРИ}

1. Прокопов В. О. Стан та якість питної води централізованих систем водопостачання України в сучасних умовах (погляд на проблему з позицій гігієни) / В. О. Прокопов // Гігієна населених місць. - 2014. № 64. - С. 56-67.

2. Прокопов В. О. Оцінка якості питної води з підземних вододжерел України з погляду впливу на стан здоров'я населення / В. О. Прокопов, О. Б. Липовецька // Наук. вісн. НМУ. - 2012. - Вип. 4. - С. 122-126.
3. Онищенко Г. Г. О санитарно-эпидемиологическом состоянии окружающей среды / Г. Г. Онищенко // Гигиена и санитария. - 2013. - № 2. - С. 4-10.

4. Волощенко О. И. Гигиеническое значение поверхностно-активных веществ / О. И. Волощенко, И. В. Мудрый. - К. : Здоровье, 2001. - 145 с.

5. Сучасний стан токсиколого-гігієнічної оцінки поверхнево-активних речовин (огляд літератури) [Електронний ресурс] / М. Г. Проданчук, І. В. Мудрий, 
О. В. Гудзь, А. А. Калашніков // Современные проблемы токсикологии. - 2006. - № 2. - Режим доступу до журн. : http://www.medved.kiev.ua/arhiv_mg/2_2006. $\mathrm{htm}$.

6. Вплив поверхнево-активних речовин на організм людини / В. І. Швець, І. Р. Тимофрійчук, С. Б. Семененко, Н. В. Швець // Клініч. та експерим. патологія. - 2017. - 16, № 2 (60). - С. 115-119.

7. Лотоцька О. В. Вплив стеарату натрію на білковоутворюючу функцію в організмі піддослідних тварин / О. В. Лотоцька // Гігієна населених місць : зб. наук. праць / редкол. : А. М. Сердюк (голов. ред.) та ін. - 2012. - № 59. - С. 87-91.

8. Мудрий І. В. Токсиколого-гігієнічна оцінка синтетичних поверхнево-активних речовин (огляд літератури) [Електронний ресурс] / І. В. Мудрий // Современные проблемы токсикологии. - 2001. - № 3. - Режим доступу до журн. : http://www.medved.kiev.ua/ arhiv_mg/st_2001/01_3_11.htm.

9. Кондратюк В. А. Санітарно-токсикологічна оцінка стеарату калію за результатами білкового обміну в експерименті / В. А. Кондратюк, О.В.Лотоцька // Гігієна населених місць : зб. наук. праць / редкол. : А. М. Сердюк (голов. ред.) та ін. - 2011. - № 58. C. 107-111.

\section{REFERENCES}

1. Prokopov, V.O. (2014). Stan ta yakist pytnoi vody tsentralizovanykh system vodopostachannia Ukrainy $v$ suchasnykh umovakh (pohliad na problemu z pozytsii hihiieny) [Condition and drinking water quality in centralized water supply systems of Ukraine for today (view on the problem with hygiene positions)]. Hihiiena naselenykh mists - Hygiene of Inhabited Areas, 64, 56-67 [in Ukrainian].

2. Prokopov, V.O., \& Lypovetska, O.B. (2012). Otsinka yakosti pytnoi vody z pidzemnykh vododzherel Ukrainy z pohliadu vplyvu na stan zdorovia naselennia [Assessment of the quality of drinking water from underground water sources in Ukraine in terms of impact on the health of the population]. Naukovyi visnyk NMU Scientific Journal of NMU, 4, 122-126 [in Ukrainian].

3. Onishchenko, G.G. (2013). O sanitarno-epidemiologicheskom sostoyanii okruzhayushchey sredy [On sanitary and epidemiological state of the environment]. Gigiyena i sanitariya - Hygiene and Sanitary, 2, 4-10 [in Russian].

4. Voloshchenko, O.I., \& Mudriy, I.V. (2001). Gigiyenicheskoe znachenie poverkhnostno-aktivnykh veshchestv [Hygienic value of surfactants]. Kiev: Zdorovye [in Russian].

5. Prodanchuk, M.H., Mudryi, I.V., Hudz, O.V., \& Kalashnikov, A.A. (2006). Suchasnyi stan toksykolohohihiienichnoi otsinky poverkhnevo-aktyvnykh rechovyn (ohliad literatury) [Modern status of toxicological and hygienic assessment of superficially active substances (literature review)]. Sovremennye problemy toksikologii Modern Problems of Toxicology, 2, http://www.medved. kiev.ua/arhiv_mg/2_2006.htm [in Ukrainian].
10. Оцінка імунотоксичної дії поверхнево-активних речовин та ензимів - складових нових синтетичних мийних засобів / О. І. Волощенко, О.В.Раєцька, О. І. Винарська, 3. Ю. Майстренко // Довкілля та здоров'я. - 2010. - № 4. - С. 12-16.

11. Стальная И. Д. Метод определения малонового диальдегида с помощью тиобарбитуровой кислоты / И. Д. Стальная, Т. Г. Гаришвили // Современные методы в биохимии. - М. : Медицина, 1971. - С. 66-68.

12. Стальная И. Д. Метод определения диеновой конъюгации ненасыщенных высших жирных кислот / И. Д. Стальная // Современные методы в биохимии / под ред. В. Н. Ореховича. - М. : Медицина, 1977. C. 63-64.

13. Чевари С. Роль супероксиддисмутазы в окислительных процессах клетки и методы ее определения в биологическом материале / С. Чевари, И. Чаба, Й. Секей // Лаб. дело. - 1988. - № 11. - С. 678-681.

14. Королюк М. А. Способ определения активности каталазы / М. А. Королюк // Лаб. дело. - 1988. № 1. - С. 6-19.

15. Реброва О. Ю. Статистический анализ медицинских данных. Применение пакета программ Statistica / О. Ю. Реброва. - М. : МедиаСфрера, 2006. $312 \mathrm{c}$.

6. Shvets, V.I., Tymofiichuk, I.R., Semenenko, S.B., \& Shvets, N.V. (2017). Vplyv poverkhnevo-aktyvnykh rechovyn na orhanizm liudyny [Influence of surface-active substances on the human organism]. Klinichna ta eksperymentalna patolohiia - Clinical and Experimental Pathology, 16, 2 (60), 115-119 [in Ukrainian]

7. Lototska, O.V. (2012). Vplyv stearatu natriiu na bilkovoutvoriuiuchu funktsiiu $v$ orhanizmi piddoslidnykh tvaryn [Effect of sodium stearate on protein generating function in the body of experimental animals]. Hihiiena naselenykh mists: zbirnyk nauk. Prats - Hygiene of Inhabited Areas: collection of Scientific Works, 59, 87-91 [in Ukrainian].

8. Mudrii, I.V. (2001). Toksikoloho-hihiienichna otsinka syntetychnykh poverkhnevo-aktyvnykh rechovyn (ohliad literatury) [Toxicological hygienic evaluation of synthetic top-active substances]. Sovremennye problemy toksikologii - Modern Problems of Toxicology, 3, 55-60 [in Ukrainian].

9. Kondratiuk, V.A. \& Lototska, O.V. (2011). Sanitarno-toksykolohichna otsinka stearatu kaliiu za rezultatamy bilkovoho obminu $v$ eksperymenti [Sanitary toxicological evaluation potassium stearate for the results of protein metabolism in experiment]. Hihiiena naselenykh mists: zbirnyk nauk. Prats 58, 107-111 [in Ukrainian].

10. Voloshchenko, O.I. (2010). Otsinka imunotoksychnoi dii poverkhnevo-aktyvnykh rechovyn ta enzymiv skladovykh novykh syntetychnykh myinykh zasobiv [Assessment of immunotoxic action of surfactants and enzymes components of new synthetic detergents]. Dovkillia ta zdorovia - Environment and Health, 4, 12-16 [in Ukrainian]. 
11. Stalnaya, I.D., \& Garishvili, T.G. (1971). Metod opredeleniya malonovogo dialdegida s pomoshchyu tiobarbiturovoy kisloty [Method for determination of malondialdehyde with thiobarbituric acid using modern methods in biochemistry]. V sb. Sovremennye metody v biokhimii. Moscow: Meditsyna, [in Russian].

12. Stalnaya, I.D. (1977). Metod opredeleniya diyenovoy konyugatsyi nenasyshchenykh vysshykh zhyrnykh kislot [Method for determination of diene conjugates of higher fatty acids]. Orekhovyche V.N. (Ed.). Moscow: Meditsyna [in Russian].

13. Chevary, S., Chaba, I., \& Seney, I. (1988). Rol superoksiddismutazy $v$ okislitelnykh protsessakh kletki i metody ee opredeleniya $v$ biologicheskom materiale [The role of superoxide dismutase in oxidative processes of cells and methods of its determination in biological material]. Laboratornoe delo - Laboratory Work, 11, 678-681 [in Russian].

14. Koroliuk, M.A. (1988). Sposob opredeleniya aktivnosti katalazy [Method for determination of catalase activity]. Laboratornoe delo - Laboratory Work, 1, 6-19 [in Russian].

15. Rebrova, O.Yu. (2006). Statisticheskiy analiz meditsynskykh dannykh. Primenenie paketa programm Statistica [Statistical analysis of medical data. Application of the Statistica package]. Moscow: MediaSfera [in Russian].

\section{ТЕРНОПОЛЬСКИЙ ГОСУДАРСТВЕННЫЙ МЕДИЦИНСКИЙ УНИВЕРСИТЕТ ИМЕНИ И. Я. ГОРБАЧЕВСКОГО \\ ВЛИЯНИЕ ПИТЬЕВОЙ ВОДЫ С РАЗЛИЧНЫМ СОДЕРЖАНИЕМ СТЕАРАТОВ КАЛИЯ И НАТРИЯ НА СВОБОДНОРАДИКАЛЬНЫЕ ПРОЦЕССЫ В ОРГАНИЗМЕ КРЫС}

\section{Резюме}

Вступление. Одной из причин плохого качества питьевой воды является низкое качество природной воды, которая постоянно загрязняется сточными водами промышленных и коммунальных предприятий, поверхностными стоками с полей и территорий населенных пунктов, с которыми в нее попадает большое количество токсичных веществ. Среди них не последнее место занимают поверхностно-активные вещества, такие, как стеараты калия и натрия.

Цель исследования - установить особенности перекисного окисления липидов и состояние антиоксидантной защиты при влиянии на организм подопытных животных стеаратов калия и натрия, которые поступают с питьевой водой.

Методы исследования. В работе использовали белых крыс, разделенных на 7 групп, которые в течение 25 дней употребляли воду со стеаратами в количестве, равном максимально недействующей дозе вещества (МНД), 1/2 МНД и 1/4 МНД. Определяли содержание ТБК-активных продуктов перекисного окисления липидов, диеновые конъюгаты и активность супероксиддисмутазы и каталазы в гомогенате печени.

Результаты и обсуждение. В гомогенате печени животных всех групп отмечали достоверный рост уровня диеновых конъюгатов и ТБК-активных продуктов пропорционально концентрации вещества. Также было установлено, что у крыс, которые употребляли воду с различной концентрацией стеарата калия, наблюдали угнетение энзимов антиоксидантной защиты. Употребление воды с различной кончентрацией стеарата натрия вызвало активацию этих энзимов.

Выводы. Длительное употребление подопытными животными водного раствора с концентрацией стеаратов калия и натрия в МНД и 1/2 МНД негативно влияет на состояние клеточных мембран гепатоцитов вследствие активации процессов перекисного окисления липидов, а именно ТБК-активных продуктов и диеновых конъюгатов, количество которых зависит от концентрации стеаратов в питьевой воде. Употребление подопытными животными питьевой воды с содержанием стеаратов калия и натрия в различных дозах обусловливает изменения уровня энзимов антиоксидантной защиты: вода со стеаратом калия подавляет активность этих показателей, а со стеаратом натрия - вызывает активацию.

КЛЮЧЕВЫЕ СЛОВА: стеарат калия; стеарат натрия; перекисное окисление липидов; антиоксидантная защита; ТБК-активные продукты; диеновые конъюгаты; каталаза; супероксиддисмутаза. 


\section{THE INFLUENCE OF DRINKING WATER WITH DIFFERENT CONTENT OF POTASSIUM AND SODIUM STEARATES ON FREE RADICAL PROCESSES IN THE BODY OF RATS}

\section{Summary}

Introduction. One of the reasons for the lack of quality drinking water is the poor quality of natural water, which is constantly polluted by waste water from industrial and municipal enterprises, surface runoff from the fields and territories of settlements with which it enters a large amount of toxic substances. Among them, surface-active substances such as potassium and sodium stearate are not the last.

The aim of the study - to determine the specifics of lipid peroxidation and the state of the antioxidant protection under the influence of potassium and sodium stearates on the body of the experimental rats when they enter with drinking water.

Research Methods. White rats were divided into 7 groups, which consumed water with stearates in quantities equal to the maximum non-active dose of the substance (MND), 1/2 MND and 1/4 MND for 25 days. The content of TBC-active lipid peroxidation products, diene conjugates and the activity of superoxide dismutase and catalase in liver homogenate were determined.

Results and Discussion. In the homogenate of the liver of animals of all groups, there was a significant increase in the level of diene conjugates and TBK-active products in proportion to the concentration of the substance. It was also found that in animals that consumed water with different concentrations of potassium stearate, inhibition of antioxidant enzymes was observed. Consumption of water with different concentrations of sodium stearate caused the activation of these enzymes.

Conclusions. Prolonged use by test animals of aqueous solution with concentrations of potassium and sodium stearate in MND and 1/2 MND negatively affects the state of hepatocyte cell membranes due to the activation of the lipid peroxidation processes, namely TBK-active products and diene conjugates, the amount of which depended on the concentration of stearates in drinking water. The use of drinking water by test animals with maintenance of potassium and sodium stearates at various doses caused changes in the content of antioxidant enzymes: water with potassium stearate inhibits the activity of these indicators, and causes sodium activation with sodium stearate.

KEY WORDS: potassium stearate; sodium stearate; lipid peroxidation; antioxidant defense; TBK-active products; diene conjugates; catalase; superoxide dismutase.

Отримано 12.01.18

Адреса для листування: О. В. Лотоцька, Тернопільський державний медичний університет імені І. Я. Горбачевського, майдан Волі, 1, Тернопіль, 46001, Україна, e-mail: lototska@tdmu.edu.ua. 